\author{
Prof. dr. sc. Nataša Žunić Kovačević \\ Pravni fakultet Sveučilišta u Rijeci
}

\title{
POSLJEDICE I UČINCI PANDEMIJE BOLESTI COVID-19 NA FISKALNI SUSTAV I OPOREZIVANJE
}

\author{
UDK: $336.2: 616.2-036.21$ \\ DOI: $10.31141 /$ zrpfs.2021.58.140.483 \\ Izvorni znanstveni rad \\ Primljeno: 23. 3. 2021.
}

\begin{abstract}
Odgovor javnih politika na pandemiju COVID-a 19 u većini država svijeta imao je izravan i velik utjecaj na fiskalne sustave. Mjere koje se poduzimaju u svim javnim politikama kako bi se suzbila ili umanjila pandemija odražavaju se na fiskalnu politiku u svim njezinim segmentima, što je posebno vidljivo na rashodnim i prihodnim segmentima fiskusa jer je riječ o utjecaju na proračune, njihove prihodne i rashodne strane. Jasno, fiskalni odgovor na zdravstvenu i posljedičnu, širu gospodarsku krizu, pokazuje uspješnost ili neuspješnost financijskog upravljanja javnim sektorom. Pokazatelji krize govore o dramatičnim učincima na javne financije i fiskalni sustav u cjelini. Fiskalni sustav sa svojim mjerama istodobno je instrument borbe protiv pandemije, ali jednako je njome pogođen: javni prihodi u prva tri su mjeseca smanjeni za 15-30 posto, a istodobno su rashodi povećani za nekih 30-40 posto, u usporedbi s istim razdobljem prethodne godine. Takav negativni učinak pojačava se rastućim deficitom te rastućim javnim dugom. Mjere koje se poduzimaju u okviru svih javnih politika kratkoročne su i podložne stalnim prilagodbama, što je i nužno s obzirom na brzomijenjajuće društveno, ekonomsko, socijalno pa i fiskalno okruženje i okolnosti. Moguće je pratiti koordinaciju u odgovorima na krizu na međunarodnoj razini, ali i europsku pa onda i nacionalnu reakciju i mjere na krizu. OECD i Europska unija pripremaju dugoročne mjere i instrumente, a na razini Unije je, uz druge instrumente, ponuđen privremeni instrument SURE. Vremenska dimenzija mjera koje se poduzimaju posebno je značajna s obzirom na brzinu promjena svih navedenih okolnosti. Visoka razina zaduženosti privatnog i javnog sektora koja se povećava u pandemiji COVID-a imat će dugoročne posljedice na fiskalni sustav u cjelini. Vrste i način donošenja odluka o svim mjerama suzbijanja pandemije te njihovi fiskalni učinci i nakon prestanka pandemijske krize mogli bi usporiti skoru, najavljenu fiskalnu decentralizaciju. Javne financije doživjet će prilagodbu, kroz primjenu klasičnih, ali i prilagođenih instrumenata te kreiranje novih instrumenata fiskalne politike za suzbijanje postojeće, ali i eventualnih budućih kriza.
\end{abstract}

Ključne riječi: fiskalni sustav, mjere javne politike, pandemija COVID-a i kriza, SURE, javne financije

\section{UVODNA RAZMATRANJA}

Izbijanje pandemije bolesti COVID-19 rezultiralo je ozbiljnom zdravstvenom, ali i ekonomskom krizom te padom ekonomske aktivnosti, sve bez presedana $\mathrm{u}$ novijoj povijesti. Obuzdavanje i ublažavanje širenja virusa te posljedica epidemije 
i mjera za njezino suzbijanje u društvu prioritet je svih javnih vlasti, s ciljem da se smanji učestalost bolesti, ograniči pritisak na zdravstvene sustave i da se eventualno svi pripreme i za neki snažniji oporavak po ublažavanju poduzetih mjera. Takve, odlučne mjere poduzimaju se u velikoj neizvjesnosti u pogledu brojnih pitanja, ali su neophodne za rješavanje zdravstvene i ekonomske krize. Mjere suzbijanja i ublažavanja pandemije imale su i imat će duboke ekonomske učinke, a procjene OECD-a sugeriraju da bi mjere ograničavanja kao odgovor na zdravstvenu i pandemijsku krizu u mnogim gospodarstvima mogle dovesti do početnog pada proizvodnje između petine i četvrtine u odnosu na proizvodnju prije izbijanja krize, pri čemu bi potrošnja potrošača u početku pala za otprilike jednu trećinu, a pad bi, dugoročno promatran, mogao biti i veći. ${ }^{1}$ Takve, doduše, grube naznake koje zahvaćaju samo izravne učinke brojnih ekonomskih i drugih ograničenja što rezultiraju iz krize izazvane pandemijom potvrda su stvaranja vrlo velike nesigurnosti na svim razinama društvenog života. ${ }^{2}$ Drugim riječima, neizvjesnost oko razvoja pandemije i trajanja napora potrebnih za suzbijanje i ublažavanje virusa velika je. Razvoj pandemije također će ovisiti o kontinuiranim naporima da se proširi sposobnost ispitivanja i praćenja poboljšanja liječenja za one s ozbiljnim simptomima te razvoja cjepiva.

Mnoge su zemlje već snažno djelovale kako bi ograničile ekonomske poteškoće uzrokovane izravnim učincima mjera suzbijanja. Fokus mjera ekonomske politike bio je na pružanju potpore likvidnosti poduzećima kao pomoć za opstanak te na pružanju potpore u dohotku ranjivim kućanstvima. ${ }^{3}$ Iako su potrebne i daljnje i koordinirane akcije za očuvanje ekonomskih kapaciteta i zaštitu najugroženijih, odgovor javnih politika mora biti razmjeran takvim nepovoljnim utjecajima i rizicima. Multilateralna i globalna suradnja i koordinacija iznimno su značajni u učinkovitosti odgovora do oporavka i u jačanju otpornosti globalnog gospodarstva na buduće šokove. U tom pogledu, međunarodno koordinirani akcijski plan G20 za suočavanje s COVID-om 19 može imati velike koristi, zahvaljujući prelijevanju iz zajedničkog djelovanja za globalno gospodarstvo.

Odgovor fiskalne politike na navedene izazove ključan je dio javnih politika. Moguće je govoriti o svojevrsnom etapnom ili parcijalnom provođenju mjera u odgovoru na pandemiju, od potpora u fazi ograničavanja poteškoća i posljedica pandemijske i ekonomske krize do održavanja i jačanja ekonomskih kapaciteta kroz poticaje za gospodarski oporavak kada se mjere suzbijanja i ublažavanja pandemije ublažavaju te konačno elemenata s dugoročnim učinkom, ali i zadržavanjem u fiskalnom sustavu. Ukidanje mjera suzbijanja i ublažavanja pandemijske krize bit će postupno i parcijalno, pri čemu valja voditi računa o horizontalnom učinku već u fazi poduzimanja prvih mjera kako se ne bi produbio već postojeći jaz u ravnomjernosti

1 OECD (2020), OECD Economic Outlook, Volume 2020 Issue 2: Preliminary version, No. 108, OECD Publishing, Paris, https://doi.org/10.1787/39a88ab1-en.(20.12.2020.)., str. 8. i dr.

2 OECD (2020), str. 29.

3 Martin, Fernando, Economic Realities and Consequences of the COVID-19 Pandemic - PART II: „The Economy and Fiscal Policy“, Economic Synopses, br. 11, 2020., dostupno na: https://doi. org/10.20955/es.2020.11(5. XII. 2020.). 
razvoja s jednako neželjenim neravnomjernim oporavkom društava. U državama sa slabije uređenim zdravstvenim sustavom te manjeg opsega fiskalne i monetarne politike, u suočavanju s pandemijom dominiraju čimbenici koji ograničavaju sposobnost odgovora na zdravstvene i ekonomske izazove. Stoga će međunarodna i europska koordinacija s elementima financijske potpore biti potrebna kao dopuna mjerama, napose fiskalne politike, što ih poduzimaju takve države na nacionalnoj, pojedinačnoj razini.

\section{FISKALNA POLITIKA KAO INSTRUMENT ODGOVORA NA PANDEMIJSKU KRIZU}

Vlade velikog broja država odgovorile su brzim i opsežnim mjerama fiskalne politike na pandemijsku, zdravstvenu i ekonomsku krizu. Iako postoje velike razlike u obuhvatu i veličini fiskalnih paketa, svi su bili jednako usmjereni na ublažavanje neposrednog utjecaja naglog pada ekonomske aktivnosti na poduzetnike, tvrtke i kućanstva te posebno na očuvanje proizvodnih kapaciteta. Svakako, izazovi u pripremi i provedbi fiskalnih paketa, mjere fiskalne politike posebno su obuhvaćale pitanje kriterija i definiranja potrebitosti i nužnosti, kako bi potpore bile targetirane, koliko je moguće usmjerene gdje je ,najhitnije“ potrebno. Takvi administrativni izazovi prisutni su kako od početka izbijanja krize i planiranja mjera tako i cijelo vrijeme trajanja krize.

Održavanje poslovnih novčanih tijekova, drugim riječima očuvanje opstanka poduzetnika cilj je svih mjera fiskalne politike uz potporu monetarne i šire, financijske politike. Monetarna politika u ovoj krizi ima važnu ulogu, ali takve su mogućnosti poticanja gospodarske aktivnosti ograničene u zdravstvenoj krizi i ograničenjima gospodarskih djelatnosti. Ipak, monetarna politika može stvarati i održavati povoljnije uvjete financiranja za sve gospodarske sektore i kućanstva. Dodatno, zadaća je monetarne politike i državi osigurati povoljnije ili što jeftinije financiranje i samih izvanrednih mjera koje poduzima u borbi protiv pandemije COVID-a. Povoljniji uvjeti financiranja omogućit će održanje gospodarskih aktivnosti privatnog sektora te pokretanje gospodarskog oporavka nakon zaustavljanja pandemije. Monetarna politika treba olakšati teret duga i javnom i privatnom sektoru, no niske kamatne stope i trend pada kamatnih stopa koji traje već desetljećima, a u takvim uvjetima strukturno niskih kamatnih stopa ta ista monetarna politika nema posebnih mogućnosti upravljanja poslovnim ciklusima. Stoga monetarna politika poseže za nekonvencionalnim mjerama koje imaju i svoje brojne negativne posljedice. ${ }^{4}$

4 Provash Kumer SARKER, 2020., „Covid crisis: Fiscal, monetary and macro-financial policy responses", Theoretical and Applied Economics, Asociatia Generala a Economistilor din Romania AGER, vol. 0(3(624), A), str. 41-54, dostupno na: https://ssrn.com/abstract=3601524 (18. X. 2020.). 
Unutar mjera fiskalne politike posebno su značajne mjere porezne politike koje obuhvaćaju mjere formalne i materijalne naravi. ${ }^{5}$ Naime, porezni postupak u svojim je segmentima prilagođen takvim okolnostima i dijelom fleksibiliziran pa su tako mjere uključivale produljenje rokova za prijavu poreza, digitalizaciju i jačanje uloge e-usluga poreznih tijela, odgodu plaćanja poreza te skraćenje rokova povrata poreza. U materijalnim mjerama porezne politike, standardno brojnijim i sveobuhvatnijim, nalaze se proširena porezna izuzeća i umanjenja osnovice, uključujući i doprinose, naknade za nadoknadu. Za razliku od poreznih mjera usmjerenih poduzetnicima, kada je riječ o fizičkim osobama u smislu kućanstva, obitelji kao jedinice ili zajednice potrošnje, tada je naglasak na mjerama na strani rashoda, u pravilu u potporama u vidu transfera iz proračuna kao ciljanim novčanim naknadama. Dakle, porezno rasterećenje u pravilu nije mjera fiskalne politike koja bi u suzbijanju pandemijske krize bila usmjerena na dohodak pojedinca, fizičke osobe, a to je sukladno financijsko-pravnoj teoriji. Ipak, materijalno-pravne porezne mjere u smislu intervencija u porezne stope i osnovice pojedinih poreznih oblika percipiraju mnogi kao odgovor fiskalne politke na pandemijsku krizu iako je riječ o segmentu hrvatske „dugoročne“ porezne reforme koja se zadnjih godina provodi u ,krugovima“. 6

Dodatno, vrijedi primijetiti kako države primjenjuju i „lockdown“ ili zaključavanje cijelog gospodarstva i društva u smislu zabrane kretanja rada, kao epidemiološku mjeru u borbi protiv zaraze, što ima velik utjecaj na fiskalni sustav i mjere koje se poduzimaju. Socijalni troškovi zaključavanja potvrđuju da je riječ o izazovima bez presedana jer, s jedne strane, kriza dovodi do naglog smanjenja fiskalnih prihoda, a istodobno je neophodan veliki fiskalni napor da bi se očuvalo poduzetništvo te ublažio rast siromaštva i nejednakosti kao kriza izazvanih „lockdownom“ i pandemijom. ${ }^{7}$

5 Vidi: Tax Measures in Response to the COVID-19 Outbreak, and Tax and Customs Administration Responses to the COVID-19 Crisis (IMF FAD, March 2020), dostupno na: https://www.imf.org/ /media/ Files/Publications/covid19-special-notes/enspecial-series-on-covid19revenue-administration-responsesto-covid19-crisissafeguarding-revenues-f.ashx (20. X. 2020.).

6 Riječ je o tzv. 5 krugova porezne reforme, gdje svaka godina primjene novog poreznog okvira predstavlja krug: prvi je krug predstavljen promjenama koje su stupile na snagu 1. siječnja 2017., a potom slijede krugovi: 2. - 2018., 3. - 2019., 4. - 2020. te posljednji 5. krug porezne reforme koji stupa na snagu 1. siječnja 2021., a obuhvaća i mjere suzbijanja pandemijske krize uz ranije započete promjene strukture i obilježja poreznog sustava. Vidi više, https://vlada.gov.hr/vijesti/peti-krug-porezne-reforme-rasterecenjevise-od-10-milijardi-kuna-uz-neoporezive-primitke-i-vise/30766(25. XI. 2020.).

7 Economic and social consequences of human mobility restrictions under COVID-19, Giovanni Bonaccorsia, 1, 2, Francesco Pierrib, 1, Matteo Cinellic, Andrea Floria, Alessandro Galeazzid, Francesco Porcellie, Ana Lucia Schmidtf, Carlo Michele Valensiseg, Antonio Scalac, Walter Quattrociocchif and Fabio Pammollia, dostupno na https://www.pnas.org/content/117/27/15530. 


\section{PRIKAZ FISKALNIH POSLJEDICA U HRVATSKOJ USLIJED ODGOVORA NA PANDEMIJU - RAST JAVNIH RASHODA, DEFICITA I DUGA}

U izvanrednim okolnostima koje je izazvala pandemija COVID-a, Vlada RH poduzela je nekoliko vrsta mjera radi ostvarenja ekonomskih ciljeva i to: očuvati ili spriječiti udar na likvidnost gospodarstva i poduzetnika te kućanstava uz očuvanje radnih mjesta. U razmatranju učinkovitosti tih mjera, treba uočiti razliku u odnosu na poduzimanje epidemioloških mjera sa ciljem sprečavanja širenja zaraze koje se uvode stupnjevano i postaju sve rigoroznije. Gospodarstvo već sada zahtijeva određenu razinu izvjesnosti što može očekivati u idućih nekoliko mjeseci jer i gospodarstvenici poslovne odluke moraju donositi jednako pravodobno i brzo. Svaka mjera Vlade podrazumijeva bilo smanjenje državnih prihoda, bilo rast rashoda te povećava potrebu za zaduživanjem, pa će država morati odustati i od nekih fiskalnih rashoda planiranih u doba kada krize nije bilo niti se mogla predvidjeti.

Dodatno, vrijedi ukazati da je Europska komisija u okviru odgovora na pandemiju suspendirala fiskalna pravila iz Pakta o stabilnosti i rastu, kako bi članicama Europske unije dala priliku za primjerenu fiskalnu reakciju, ali to ne isključuje fiskalnu odgovornost te država mora voditi računa o dugoročnim posljedicama fiskalne politike koju trenutno vodi i kao odgovor na pandemijsku krizu. U tome se mogu primijetiti razlike u fiskalnim kapacitetima i mogućnostima fiskalnih odgovora, od države do države. No, kada je ekonomija u recesiji, kao što je trenutna, uzrokovana pandemijom, i kada postoji snažan negativan šok na strani i ponude i potražnje, tada je neophodna posebno ekspanzivna fiskalna politika uz potporu drugih javnih, napose monetarne politike. ${ }^{8}$ Odgovor fiskalne politike upravo je u fiskalnoj ekspanziji i povećavanju deficita što može ublažiti takav šok na strani potražnje i ponude te očuvati radna mjesta i zaposlenost.

\section{UKRATKO O OKOLNOSTIMA U HRVATSKOJ}

Prvi je slučaj bolesti COVID-19 u Hrvatskoj potvrđen u Zagrebu 25. veljače 2020., mladiću koji se u zemlju vratio iz Italije (Milano). Odluka o prvom „lockdownu“ donesena je u istarskoj regiji, 11. ožujka 2020., što je zatim prošireno na cijelu zemlju i to 16. ožujka 2020. Već tada se propisuju sankcije za kršenje samoizolacije, novčane (8000 - 120.000 kuna) ili kaznene, do 3 godine zatvora. Slabljenje ili p/opuštanje ,antikorona“ mjera bilo je osigurano u 3 koraka. Podaci o oboljelima govore da je do 14. rujna 2020. bilo ukupno 13.598 zaraženih, dok je ukupno oporavljeno tada bilo 11.151, a ukupno umrlih njih 227.

8 Bonatti, L., Fracasso, A., Tamborini, R., Rethinking Monetary and Fiscal Policy in the PostCOVID Euro Area. Publication for the Committee on Economic and Monetary Affairs, Policy Department for Economic, Scientific and Quality of Life Policies, European Parliament, Luxembourg, 2020. 
Utjecaj „lockdowna“ na fiskus pokazuje se kroz probleme povezane s javnim financiranjem jer su smanjeni prihodi i dolazi do velikog rasta rashoda uz povećanje deficita državnog proračuna već za cca 3 milijarde eura te povećanje javnog duga. ${ }^{9}$ Sve navedeno ostavlja posljedice na cijeli fiskalni sustav i dovodi do potrebnih promjena u poreznom sustavu. Posljedice u fiskalnom sustavu vidljive su posebno kao smanjenje svih javnih prihoda, kako poreznih, tako i neporeznih. Istodobno rastu javni rashodi odnosno javna potrošnja kroz dodijeljene olakšice, ali i potpore i pomoći, uz najavljena porezna rasterećenja. S ciljem kratkotrajnog djelovanja i pomoći donesene su već u ožujku 2020. godine mjere, usklađene s gospodarskim udruženjima i sindikatima te sa zajedničkim europskim naporima za suzbijanje ekonomskih šteta od koronavirusa. Prvi dio tih mjera horizontalne je naravi i odnosi se na one koji već osjećaju ili će tek osjetiti posljedice epidemije. To se odnosi na odgodu plaćanja javnih davanja, konkretno odgodu plaćanja poreza na dohodak i poreza na dobit te doprinosa na plaće i to na tri mjeseca, uz mogućnost produženja na još tri, a nakon toga omogućuje se obročna otplata duga na 24 mjeseca. U paketu mjera koje se odnose na financijsku likvidnost ${ }^{10}$ jest $\mathrm{i}$ instrument moratorija, $\mathrm{i}$ to na obveze prema HBOR-u i komercijalnim bankama ${ }^{11}$ od tri mjeseca, odobrenje kredita za likvidnost za isplatu plaća i dobavljača te reprogram drugih obveza. U planu mjera su i beskamatni zajmovi općinama, gradovima i županijama, Hrvatskom zavodu za zdravstveno osiguranje i Hrvatskom zavodu za mirovinsko osiguranje do visine poreza na dohodak, prireza i doprinosa čije je plaćanje odgođeno i/ili je odobrena obročna otplata. ${ }^{12}$

Uz promjene u poreznom sustavu, kao odgovor na pandemijsku krizu dolazi i do izmjena u sustavu parafiskaliteta te pojednostavljenje postupka ubiranja javnih davanja s pojačanim i pojednostavljenim postupcima odgode naplate javnih davanja.

U poreznom sustavu mogu se uočiti učinci krize kroz izmjene na sustavnoj razini, samog procesnog okvira u odredbama Općeg poreznog zakona ${ }^{13}$ te izmjene na posebnim elementima pojedinih poreznih oblika, dakle kroz porezno-materijalni

9 Smjernice za izradu Državnog proračuna Republike Hrvatske za 2021. i projekcija za 2022. i 2023. https://mfin.gov.hr/UserDocsImages/dokumenti/publikacije/smjernice/Smjernice\%20za\%20izradu\%20 DP\%20RH\%20za\%202021\%20i\%20projekcija\%20za\%202022\%20i\%202023.pdf (20. XI. 2020.).

10 Zakon o interventnim mjerama u ovršnim i stečajnim postupcima za vrijeme trajanja posebnih okolnosti, Narodne novine, 53/20., 83/20.

11 Vidi, i koordiniranu aktivnost - Interpretativna komunikacija Komisije o primjeni računovodstvenih i bonitetnih okvira za olakšavanje bankovnog kreditiranja u EU-u, Potpora poduzećima i kućanstvima u kontekstu krize uzrokovane bolešću COVID-19, COM/2020/169 final, dostupno na: https://eur-lex. europa.eu/legal-content/HR/TXT/?uri=CELEX:52020DC0169 (6. VI. 2020.).

12 Odluka o usvajanju Programa dodjele državnih potpora sektoru mora, prometa, prometne infrastrukture i povezanim djelatnostima u aktualnoj pandemiji COVID-a 19, Narodne novine, 77/20., 116/20., 5/21., Odluka o donošenju Smjernica politike državnih potpora za razdoblje 2021. - 2023., Narodne novine, 148/20.

13 Zakon o dopuni Općeg poreznog zakona s početkom važenja 20. III. 2020., Narodne novine 32/2020, Zakon o dopuni Općeg poreznog zakona, Narodne novine 42/2020, sa stupanjem na snagu 8 . IV. 2020 
okvir. ${ }^{14}$ To su izmjene u sustavu poreza na dobit, izmjene u sustavu poreza na dohodak, izmjene u sustavu poreza na dodanu vrijednost te izmjene u oporezivanju prometa i nekretnina.

Kao dio jednoga od više ciklusa kontinuirane hrvatske porezne reforme, kao dugoročni učinak sa zadržavanjem predloženog rješenja, najavljena je mjera u sustavu poreza na dobit u vidu snižavanja stope poreza na dobit za mala poduzeća, ona s godišnjim prihodom do milijun eura - 12 posto na 10 . Valja primijetiti kako takva poduzeća u Hrvatskoj čine 93 posto svih aktivnih i postojećih „tvrtki“ u Hrvatskoj. Drugim riječima, to znači da bi snižena stopa bila primjenjiva na neto dobit oko 100.000 tvrtki. Mjera produljenja roka za plaćanje predujma za poduzetnike primjer je pravodobnog odgovaranja na potrebe gospodarstvenika.

Slično je s mjerama u sustavu oporezivanja dohotka gdje se poduzimaju mjere s dugoročnim učinkom te namjeravanim zadržavanjem rješenja u sustavu i po prestanku krize izazvane pandemijom. U sustavu je poreza na dohodak predviđeno snižavanje poreznih stopa s promjenom poreznih razreda i to gornje porezne stope sa 36 na 30 posto te niže porezne stope sa 24 na 20 posto. Zadržavanje progresivnog oporezivanja iz više je razloga bilo potrebno te moguće potvrđuje i takvo opredjeljenje s ciljem daljnjih nastojanja izgradnje pravednog poreznog sustava općenito. U sustavu oporezivanja potrošnje najmanje je predviđenih mjera, pa je očekivano u tom segmentu i manje prisutnih mjera s dugoročnim učinkom odnosno mjera čija bi rješenja bila zadržana po prestanku epidemije i njome uzrokovane krize. Ipak, i tu su mjere koje dovode do veće javne potrošnje jer se proširuje obuhvat roba i usluga sa sniženom stopom poreza na dodanu vrijednost dok se snižena stopa PDV-a od 13 posto predviđa za svu hranu.

Navedeno ukazuje da su moguće pozitivne dugoročne posljedice i učinci provedbe kratkoročnih mjera i politika koje se poduzimaju unutar fiskalnog sustava s ciljem suzbijanja pandemijske krize. Ipak, može se primijetiti kako su mjere koje se poduzimaju na prihodnoj strani, odnosno u okviru poreznog sustava i pojedinih poreznih oblika više rezultat ranije postavljenih ciljeva reforme poreznog sustava. Kratkoročne mjere unutar poreznog sustava koje su procesne naravi, poduzete su radi olakšavanja trenutnog poreznog položaja gospodarstvenika, imaju pozitivan učinak za porezne obveznike, no nije riječ o sustavnim rješenjima koja bi mogla biti zadržana po prestanku krize.

Dugoročne posljedice mjera porezne politike protiv COVID-a 19 i pozitivni dugoročni učinci mogu se naći u zadržavanju rješenja koje se prikazuje kao smanjeno oporezivanje rada ili dohotka od rada.

14 Doduše, takve izmjene i prilagodbe kriznim i izvanrednim okolnostima moguće je trebalo provesti normama koje ne diraju sustavna rješenja pa tako mogu biti norme podzakonske snage; posebno su važne upute, smjernice, vodiči koji su usmjereni poreznim tijelima i administraciji, ali i poreznim obveznicima. Tax Law Design Considerations When Implementing Responses to the COVID-19 Crisis, Special Series on Tax Law Design Issues to Respond to COVID-19, available at https://www.imf.org/ /media/Files/ Publications/covid19-special-notes/special-series-on-covid-19-tax-law-design-considerations-whenimplementing-responses.ashx?la=en (12. XII. 2020.). 
Krizne okolnosti potvrđuju da je i dalje prisutna potreba redefiniranja pristupa oporezivanju imovine i nekretnina, iako financijsko-pravna teorija kroz temeljne postulate i porezna načela jasno artikulira pravilo po kojem u kriznim vremenima nema mjesta povećanju poreznog opterećenja. ${ }^{15}$ No, težina trenutne situacije s naglašenom potrebom za poreznim rasterećenjem dohodaka ukazuje na dugoročno održivo rješenje u preraspodjeli dosadašnjeg poreznog tereta na imovinu i nekretnine poreznih obveznika što je, uz ostalo, učinkovit mehanizam za povećanje poreznih prihoda, poglavito lokalnih vlasti.

Diferencijacija poreznog opterećenja prema poreznoj snazi i veličini dohotka kroz oporezivanje dohotka doprinosi i potrebnom smanjenju nesocijalnosti poreza na dodanu vrijednost pa mjera zadržavanja progresije u tom dijelu poreznog sustava ima dugoročan i pozitivan učinak.

Mjere koje se poduzimaju u fiskalnom sustavu u obliku raznovrsnih potpora i pomoći, kao kratkoročne mjere imaju poglavito negativan kratkoročni učinak na fiskus, u smislu povećanja rashoda odnosno javne potrošnje. Takve mjere pokazuju dugoročnu neodrživost, pri čemu dodatno treba razraditi socijalne kriterije kod mjera usmjerenih fizičkim osobama dok na razini poduzetnika u mjere valja uključiti procjenu i smanjenje rizika stvaranja ovisnosti o pomoći kao dugoročnog negativnog učinka poduzetih mjera.

\section{EUROPSKA I MEĐUNARODNA KOORDINACIJA U ODGOVORU NA PANDEMIJSKU KRIZU I UTJECAJ NA NACIONALNE FISKALNE SUSTAVE}

Europska je komisija već 20. ožujka 2020. donijela Komunikaciju o aktivaciji opće klauzule o odstupanju iz Pakta o stabilnosti i rastu. Ta klauzula olakšava koordinaciju proračunskih politika u vrijeme ozbiljnog gospodarskog pada, kako je određeno odredbama Uredbe 1466/97 o jačanju nadzora stanja proračuna i nadzora i koordinacije ekonomskih politika ${ }^{16}$ te odredbama Uredbe 1467/97 o ubrzanju i pojašnjenju provedbe postupka u slučaju prekomjernog deficita. ${ }^{17}$ Komisija je u Komunikaciji Vijeću iznijela stajalište da trenutni uvjeti dopuštaju aktivaciju te klauzule zbog očekivanog ozbiljnog gospodarskog pada prouzročenog pandemijom bolesti COVID-19. Aktivacijom opće klauzule o odstupanju dopušta se privremeno odstupanje od fiskalnih pravila pod uvjetom da se time srednjoročno ne ugrozi fiskalna održivost. Aktivacijom opće klauzule o odstupanju ne obustavljaju se

15 Bejaković, P., „Obilježja i promjene oporezivanja dohotka i dobiti u novom tisućljeću“, Porezni vjesnik, br. 7-8, 2016., str. 115.

16 Uredba Vijeća (EZ) br. 1466/97 od 7. srpnja 1997. o jačanju nadzora stanja proračuna i nadzora i koordinacije ekonomskih politika, OJ L 209, 2. VIII. 1997., str. 1-5, članak 5. stavak 1., članak 6. stavak 3., članak 9. stavak 1. i članak 10. stavak 3. Uredbe 1466/97.

17 Uredba Vijeća (EZ) br. 1467/97 od 7. srpnja 1997. o ubrzanju i pojašnjenju provedbe postupka u slučaju prekomjernog deficita, OJ L 209, 2. VIII. 1997., str. 6-11., v. članak 3. stavak 5. i članak 5. stavak 2. Uredbe $1467 / 97$. 
postupci u okviru Pakta o stabilnosti i rastu, nego se državama članicama omogućuje da odstupe od proračunskih zahtjeva koji bi se obično primjenjivali, a Komisiji i Vijeću da u okviru Pakta poduzmu potrebne mjere za koordinaciju politika. ${ }^{18}$

Europska je unija promptno odgovorila i ponudila jedan novi instrument, uz nekoliko postojećih. Komisija je već 13. ožujka 2020. objavila Komunikaciju Europskom parlamentu, Europskom vijeću, Vijeću, Europskoj središnjoj banci, Europskoj investicijskoj banci i Euroskupini o „koordiniranom gospodarskom odgovoru na pandemiju COVID-a 19". ${ }^{19}$ U području gospodarstva predložila je investicijsku inicijativu kao odgovor na koronavirus, koja bi trebala omogućiti fleksibilno korištenje strukturnih fondova EU-a radi reakcije na brzorastuće potrebe u najizloženijim sektorima, kao što su zdravstvo, mala i srednja poduzeća i tržišta rada, te pružanja pomoći najugroženijim područjima u državama članicama i njihovim građanima. Taj je prijedlog stupio na snagu već 30. ožujka 2020. godine. Komisija je donijela i Privremeni okvir za državne potpore zahvaljujući kojem će države članice moći iskoristiti potpunu fleksibilnost predviđenu pravilima o državnim potporama kako bi poduprle svoja gospodarstva. Uz to (amplius supra), Komisija je pozvala Vijeće da se pobrine da sve institucije Unije aktiviraju opću klauzulu o odstupanju u okviru Pakta o stabilnosti i rastu, a primijenit će je kao dio strategije Unije za brz, odlučan i koordiniran fiskalni odgovor na pandemiju bolesti COVID-19. ${ }^{20} \mathrm{U}$ okviru zajedničkog koordiniranog odgovora donesen je i Komisijin prijedlog da se područje primjene Fonda solidarnosti EU-a (dalje: EUSF) proširi na izvanredna stanja velikih razmjera u području javnog zdravlja i da se definiraju posebne operacije koje ispunjavaju uvjete za financiranje, što je ojačalo solidarnost Unije s državama članicama u rješavanju krizne situacije.

Uz navedeni, stalni, pravni instrument Unije za pružanje potpore državama članicama u izvanrednim situacijama, ${ }^{21}$ donesen je i instrument privremene naravi - SURE (engl. Support to mitigate Unemployment Risks in an Emergency, dalje: SURE) kako bi se osigurala financijska potpora u području javnog zdravlja i kako bi se definirale posebne aktivnosti i mjere koje ispunjavaju uvjete za financiranje.

Dok je EUSF po cilju i naravi trajni instrument, SURE je privremene naravi, jer se EUSF može upotrebljavati trajno, dok je instrument SURE ograničen na slučaj pandemije bolesti COVID-19. Razlikuje se i prostorno područje primjene jer je SURE ograničen na države članice i ne obuhvaća zemlje koje pregovaraju o pristupanju Uniji. Doduše, predmetno je područje primjene obaju instrumenata jednako jer se jednako odnose na rješavanje velikih kriza koje su posljedica :PDF.

18 Izvješća EK, https://eur-lex.europa.eu/LexUriServ/LexUriServ.do?uri=COM:2020:0535:FIN:HR

19 Komunikacija o globalnom odgovoru EU-a na COVID-19, https://eur-lex.europa.eu/legal-content/ HR/TXT/PDF/?uri=CELEX:52020JC0011\&from=EN. (20. XI. 2020.).

20 Odluka o koordinaciji aktivnosti unutar okvira za gospodarsko upravljanje Europske unije, Narodne novine, 13/17., 51/17., 97/17., 50/18., 74/19., 16/20., 89/20.

${ }_{21}$ Uredba Vijeća (EZ) br. 2012/2002 od 11. studenoga 2002. o osnivanju Fonda solidarnosti Europske unije (EUSF) - Uredba (EZ) br. 2012/2002. Uredba (EU) 2020/461 Europskog parlamenta i Vijeća širi područje primjene na izvanredna stanja velikih razmjera. 
javnozdravstvenih prijetnji. EUSF se temelji na bespovratnim sredstvima $\mathrm{i}$ omogućuje isplatu predujmova, dok se instrument SURE temelji na zajmovima. Mobilizacija financijske pomoći Unije u okviru instrumenta SURE moguća je samo na prijedlog Komisije Vijeću. Dotična država članica trebala bi zatražiti potporu. Komisija bi se, prije nego što Vijeće dodijeli financijsku pomoć u okviru instrumenta SURE, trebala savjetovati s dotičnom državom članicom kako bi procijenila razmjere iznenadnog i znatnog povećanja javnih rashoda u području zaštite radnih mjesta. Država članica bi pri podnošenju zahtjeva za potporu trebala dostaviti dokaze o tom iznenadnom i znatnom povećanju stvarnih, a potencijalno i planiranih rashoda. Ako su uvjeti za dodjelu financijske pomoći u okviru tog instrumenta ispunjeni, Vijeće kvalificiranom većinom donosi provedbenu odluku o njezinu odobravanju. Komisija i država članica korisnica zaključuju sporazum o provedbi. Pri ispitivanju iznenadnog povećanja rashoda relevantne operacije ostaju ograničene na hitne operacije u javnom sektoru poduzete za zaštitu radnih mjesta zbog pandemije bolesti COVID-19. Zahvaljujući tim zajmovima, države članice moći će financirati svoje povećane javne rashode namijenjene programima skraćenog radnog vremena i sličnim mjerama kojima se štite radna mjesta, a time i zaposlene i samozaposlene osobe od rizika nezaposlenosti. ${ }^{22}$

Dosljednost u odnosu na druge politike Unije Prijedlog je dio niza mjera razvijenih kao odgovor na aktualnu pandemiju bolesti COVID-19, kao što je „Investicijska inicijativa kao odgovor na koronavirus", i njime se dopunjuju ostali instrumenti za potporu zaposlenosti, kao što su Europski socijalni fond i Europski fond za strateška ulaganja (EFSU)/InvestEU. Temelji se na metodi koju je Unija u protekloj financijskoj krizi upotrijebila u okviru Mehanizma za europsku financijsku stabilnost (EFSM) za brzo pružanje financijske pomoći državama članicama koje su se našle u poteškoćama ili su im prijetile poteškoće uzrokovane izvanrednim okolnostima izvan njihove kontrole te na novom okviru za upravljanje nepredviđenim obvezama iz Financijske uredbe iz 2018. Taj instrument za zaduživanje i pozajmljivanje pruža potporu državama članicama u ovom konkretnom slučaju pandemije bolesti COVID-19 i države članice bi ga mogle iskoristiti kao drugu crtu obrane za financiranje programa skraćenog radnog vremena i sličnih mjera kojima se štite radna mjesta, a time i zaposlene i samozaposlene osobe od rizika nezaposlenosti. Taj privremeni instrument trebalo bi smatrati izvanredno operacionaliziranim oblikom Europskog sustava reosiguranja za slučaj nezaposlenosti u posebnom kontekstu krize uzrokovane pandemijom bolesti COVID-19, ne dovodeći u pitanje moguću naknadnu uspostavu trajnog instrumenta na temelju drugačije pravne osnove $u$ UFEU-u.

22 Vijeće je odobrilo financijsku potporu u iznosu od 87,9 milijardi eura za 17 država članica. Osim toga, Komisija je 16. studenoga 2020. predložila financijsku potporu Irskoj u iznosu od 2,5 milijardi eura, koju će morati odobriti Vijeće. Sa zadnjim prijedlogom Komisije ukupna financijska potpora u okviru instrumenta SURE iznosi oko 90,3 milijarde eura. Italiji, Španjolskoj, Poljskoj, Grčkoj, Hrvatskoj, Litvi, Cipru, Sloveniji, Malti i Latviji već je ukupno isplaćena 31 milijarda eura. Vidi, https://ec.europa.eu/ info/business-economy-euro/economic-and-fiscal-policy-coordination/financial-assistance-eu/fundingmechanisms-and-facilities/sure_hr (20. X. 2020.). 
Organizacija programa zajmova i upravljanje tim programom temelji se na članku 122. stavku 2. UFEU-a, koji omogućuje da Vijeće na prijedlog Komisije, pod određenim uvjetima, odobri financijsku pomoć Unije na privremenoj i ad hoc osnovi državi članici koja se nađe u poteškoćama ili joj prijete ozbiljne poteškoće zbog prirodnih katastrofa ili izvanrednih okolnosti koje su izvan njezine kontrole. To bi bila pravna osnova komponente pozajmljivanja instrumenta SURE.

Do sada je članak 122. stavak 2. UFEU-a upotrijebljen samo jedanput. Tijekom financijske krize služio je kao pravna osnova za uspostavu privremenog Mehanizma za europsku financijsku stabilnost (EFSM) za pomoć državama članicama koje su u cijelosti ili djelomično izgubile pristup tržištu zbog iznimno nepovoljnih i sve nepovoljnijih troškova zaduživanja. Unija je taj instrument upotrijebila kako bi odobrila zajmove Irskoj i Portugalu te osigurala prijelazno financiranje za Grčku.

Članak 122. stavak 2. UFEU-a može se koristiti za sve vrste izvanrednih kriznih situacija i nije ograničen na financijske krize i krize koje utječu na financijsku stabilnost. Vijeće ima široke diskrecijske ovlasti kada je riječ o ocjeni ispunjavanja uvjeta za primjenu te pravne osnove. To je i slučaj kada je riječ o državama članicama koje su najsnažnije pogođene ozbiljnom javnozdravstvenom prijetnjom zbog pandemije bolesti COVID-19 i njezinim gospodarskim i socijalnim posljedicama. ${ }^{23}$

Sure instrument temelji se na načelima supsidijarnosti i proporcionalnosti. Supsidijarnost proizlazi iz područja neisključive nadležnosti jer je cilj SURE-a pomoći državama članicama koje su suočene s ozbiljnim gospodarskim poremećajem zbog izvanrednih okolnosti izazvanih pandemijom bolesti COVID-19 kako bi se pokazala europska solidarnost s državama članicama koje su teško pogođene i pružila im se financijska pomoć Unije u obliku privremenih zajmova. Kao druga crta obrane, tom se financijskom pomoći podupiru na privremenoj osnovi povećani javni rashodi njihovih vlada zbog programa skraćenog radnog vremena i sličnih mjera kojima se štite radna mjesta, a time i zaposlene i samozaposlene osobe od rizika nezaposlenosti i gubitka dohotka. Tom se potporom pomaže pogođenom stanovništvu, olakšava brži povratak normalnom životu u pogođenim regijama i ublažuju izravne socijalne i gospodarske posljedice izazvane aktualnom krizom zbog pandemije bolesti COVID-19. ${ }^{24}$

Proporcionalnost instrumenata SURE-a razvidna je jer je jasno da se ne prelazi ono što je potrebno za postizanje ciljeva tog instrumenta. Nomotehnički gledano, SURE je instrument koji ima oblik uredbe jer se njime uspostavlja novi poseban i privremeni instrument koji može koristiti svaka država članica te mora biti u cijelosti

23 Vidi, iz obrazloženja/konteksta prijedloga Uredbe Vijeća o uspostavi europskog instrumenta za privremenu potporu radi smanjenja rizika od nezaposlenosti u izvanrednoj situaciji (SURE) nakon izbijanja bolesti COVID-19, dostupno na https://eur-lex.europa.eu/legal-content/HR/TXT/HTML/?uri=C ELEX:52020PC0139\&from=EN. (28. VII. 2020.).

24 Iz prijedloga Uredbe (EU) 2020/672 of 19 May 2020 on the establishment of a European instrument for temporary support to mitigate unemployment risks in an emergency (SURE) following the COVID-19 outbreak, OJ L 159, 20. V. 2020., str. 1-7, o uspostavi europskog instrumenta za privremenu potporu radi smanjenja rizika od nezaposlenosti u izvanrednoj situaciji (SURE) nakon izbijanja bolesti COVID-19, COM/2020/139 final, dostupno na https://eur-lex.europa.eu/legal-content/ HR/TXT/?uri=CELEX:52020PC0139 (20. XI. 2020.). 
obvezujući iizravno primjenjiv u svim državamačlanicama. U prošlosti je, u kontekstu financijske krize, već upotrijebljena uredba Vijeća o uspostavi financijske pomoći državama članicama na temelju članka 122. stavka 2. UFEU-a kako bi se utvrdili postupci i prakse za sastavljanje i ocjenjivanje zahtjeva dotičnih država članica te financijska pomoć pružila na brz i učinkovit način. Time se osigurava primjeren i dosljedan okvir za kasnije provedbene odluke Vijeća o pružanju financijske pomoći državama članicama. Uredba koja se primjenjuje na sve države članice istodobno je najprimjereniji pravni instrument za organiziranje sustava jamstava koji služi kao podloga za odobravanje zajmova u okviru instrumenta SURE-a, s obzirom na to da se on temelji na dobrovoljnim doprinosima svih država članica. ${ }^{25}$

Uvjeti pod kojima država članica može početi koristiti potporu iz ovog instrumenta utvrđuju se ovisno o iznenadnom i znatnom povećanju stvarnih, a potencijalno i planiranih javnih rashoda za očuvanje radnih mjesta koje je uzrokovano pandemijom bolesti COVID-19 te su izravna posljedica pokretanja, produljenja ili proširenja programa skraćenog radnog vremena i drugih sličnih mjera poduzetih kao odgovor na tu situaciju. Instrument SURE predviđa se u obliku programa zajmova uz potporu sustava jamstava država članica. Takav sustav Uniji omogućuje da poveća opseg zajmova koji se mogu pružiti u okviru instrumenta SURE državama članicama koje su zatražile financijsku pomoć u okviru tog instrumenta te da osigura usklađenost nepredviđenih obveza za Uniju koje proizlaze iz tog instrumenta s proračunskim ograničenjima Unije. Da bi se tim pristupom postigli željeni rezultati, države članice moraju Uniji pružiti vjerodostojna i neopoziva jamstva plativa na poziv u skladu sa svojim udjelom u ukupnom bruto nacionalnom dohotku Unije. Sustav jamstava predviđen je da bi se izbjegla potreba da države članice unaprijed plaćaju novčane doprinose, a istodobno osigurava kreditno poboljšanje potrebno da se osigura visok kreditni rejting i zaštita proračunskih sredstava Unije. Da bi se osigurala financijska stabilnost programa, uz pružanje jamstva država članica, u okvir su ugrađene i druge zaštitne mjere: strog i konzervativan pristup financijskom upravljanju, izrada portfelja zajmova kojim se ograničava koncentracijski rizik, godišnja izloženost i prekomjerna izloženost pojedinim državama članicama te istodobno osiguravaju dostatna sredstava koja se mogu dodijeliti državama članicama kojima su najpotrebnija i mogućnost obnavljanja zajma.

Multilateralna suradnja i koordinacija imaju velik značaj u postizanju i očuvanju učinkovitog odgovora u svim fazama krize, a posebno na putu ka oporavku i jačanju globalne otpornosti gospodarstva na buduće krize i izazove. Tako međunarodno koordinirani Akcijski plan G20 za suočavanje s COVID-om 19 omogućuje ostvarenje koristi za sve države, kao posljedica prelijevanja učinaka zajedničkih aktivnosti utječući tako na cjelokupno globalno gospodarstvo. Međunarodni i globalni odgovor čini se usklađen s iskustvima iz prethodnih kriza, pa je moguće naći i elemente tradicionalnog pristupa koji vidimo u nastojanjima međunarodnih

25 Prema Prijedlogu Uredbe Vijeća o uspostavi europskog instrumenta za privremenu potporu radi smanjenja rizika od nezaposlenosti u izvanrednoj situaciji (SURE) nakon izbijanja bolesti COVID-19, COM/2020/139 final, dostupno na https://eur-lex.europa.eu/legal-content/HR/TXT/?uri= CELEX:52020PC0139 (20. XI. 2020.). 
financijskih institucija i tijela koja predviđaju financijsku pomoć i potpore. Primjer tog tradicionalnog pristupa jest zaključivanje Ugovora o zajmu između Republike Hrvatske i Međunarodne banke za obnovu i razvoj za odgovor na krizu i podršku oporavku. ${ }^{26}$

Provedbom Ugovora o zajmu podržavat će se napori za ublažavanje ekonomskog i socijalnog učinka pandemije COV1D-a 19 i očuvanje proizvodnih kapaciteta te se postavljaju temelji za uključivi i održivi ekonomski oporavak. Zajam iznosi 275.900.000 eura, a podržat će program sastavljen od devet mjera strukturiranih oko dva stupa. Prvi stup odnosi se na ublažavanje neposrednog socijalnog i ekonomskog utjecaja krize izazvane pandemijom, putem sljedećih mjera: a) Hrvatski zavod za zapošljavanje provodi mjere za: (i) osiguravanje potpora za plaću u trajanju od tri mjeseca (a) poslodavcima koji i dalje zadržavaju radnike s ugovorima na neodređeno i određeno vrijeme, kao i (b) korisnicima potpora za samozapošljavanje; i (ii) pružanje potpore za ,stalne“ sezonske radnike, b) donesene su mjere kojima se uvode novi programi financiranja za jačanje likvidnosti poduzeća u Hrvatskoj pod utjecajem krize, c) donesen je Zakon o izmjenama i dopuni Zakona o dobrovoljnom zdravstvenom osiguranju, radi povećanja dostupnosti zdravstvene skrbi za najsiromašnije, na način da je podignuta granica prihodovnog cenzusa za ostvarivanje prava na dopunsko zdravstveno osiguranje na teret sredstava državnog proračuna u 2020. za članove obitelji i samce, d) doneseni su Zakon o dopuni Općeg poreznog zakona te Pravilnik o izmjenama i dopunama Pravilnika o provedbi Općeg poreznog zakona, radi podrške likvidnosti poduzeća, (i) oslobođenjem ili odgodom plaćanja dospjelih obveza za porez na dohodak, dobit i doprinose za socijalno osiguranje prema definiranim kriterijima, (ii) omogućavanjem obročne otplate do 24 mjeseca dospjele obveze plaćanja poreza na dobit, dohodak i doprinosa za socijalno osiguranje; (iii) suspenzijom naplate zatezne kamate kod odgode plaćanja dospjelih poreznih obveza i obveza za socijalne doprinose; i (iv) uvođenjem mogućnosti plaćanja poreza na dodanu vrijednost po naplati umjesto po izdavanju računa, za sve porezne obveznike, e) donesen je Zakon o interventnim mjerama u ovršnim i stečajnim postupcima za vrijeme trajanja posebnih okolnosti, radi izmjene stečajnih postupaka i dodatnog ograničavanja mogućih stečajeva. ${ }^{27}$ Politika tijekom ograničavanja i ublažavanja posljedica pandemije i njome izazvane krize trebala bi zaštititi dohodak kućanstava i zapošljavanje i očuvati opstanak poduzetnika i njihovih poduzeća i kompanija. Kako se mjere ograničavanja i ublažavanja nastavljaju, daljnja prilagodba na brze promjene okolnosti bit će ključne. Ova faza zahtijeva preciznije planiranje i provedbu, ali i proširenje ciljeva javnih politika. Troškovi djelovanja preciznih i ciljanih politika, napose fiskalnih, bit će visoki, ali troškovi neaktivnosti čine se još većima.

26 Zakon o potvrđivanju Ugovora o zajmu između Republike Hrvatske i Međunarodne banke za obnovu i razvoj za odgovor na krizu i podršku oporavku, NN 4/2020.

27 Drugi stup grupira mjere za promicanje uključivog i održivog oporavka: a) donesen je Zakon o nacionalnoj naknadi za starije osobe $(65+)$, koje nisu ostvarile prihod od rada, odnosno za osobe koje nemaju nikakav ili imaju nedostatan prihod, b) donesen je Zakon o izmjenama i dopunama Zakona o kreditnim institucijama. 
Posebno izazovnim čini se dugoročna potreba zaštite dohodaka i zaposlenosti, dakle ne samo tijekom suzbijanja i ublažavanja posljedica predmetne krize. Prilagodljivost mjera fiskalne politike treba proizlaziti iz promjenjive naravi rizika, pa sve te mjere trebaju imati ugrađenu mogućnost produljenja svih odgoda, proširenog prijenosa gubitaka, čime se pomaže poduzetnicima koji stvaraju gubitke uzrokovane pandemijskom krizom. Porezne potpore trebaju biti ciljane jer su ishodi takvih potpora pozitivniji i sprečavaju produbljivanje nejednakosti i regresivnosti. Jednako, potpore trebaju biti ciljane i sektorske, vodeći računa o tome da mali i srednji poduzetnici trebaju imati prioritet $\mathrm{s}$ obzirom na to da teže podnose rizike nelikvidnosti i nesolventnosti.

Fiskalni poticaji bit će dugoročno potrebni za poticanje oporavka jer je nastavak održive podrške svakako pretpostavka razvoja postupnim oporavkom. To svakako ukazuje na neželjenu, ali, čini se, neizbježnu ovisnost privatnog, kao i javnog, sektora o pomoćima. Ali, svi oblici pomoći i poticaja tijekom faze oporavka trebaju biti precizni i ciljani jer postoje velike razlike, prostorne i sektorske, u potencijalu vremena i opsega izlaska iz ograničenja i ublažavanja, odnosno krize i postkrize. Svakako, sve pomoći imaju biti koliko god je moguće povezane s dugoročnim ciljevima fiskalne i drugih javnih politika. ${ }^{28}$

Pitanje koordinacije svih politika značajno je jer takve politike čine svaki poticaj učinkovitijim. Na globalnoj razini to znači da zemlje koje su najmanje pogođene i one s više potencijala za djelovanje, mogu i trebaju djelovati snažno i stvoriti pozitivne povratne učinke kroz gospodarske, trgovinske i investicijske veze, pružajući poticaj globalnoj ekonomiji, čime se posredno sudjeluje u oporavku i na nacionalnim razinama.

Moguće je jasno predvidjeti posljedice i mogućnosti porezne politike i nakon oporavka od krize, jer je za očekivati da će porezni prihodi biti znatno smanjeni i više godina, kako zbog izravnih učinaka krize, tako i zbog očekivanog djelovanja porezne politike tijekom krize. Jedan od načina za povećanje poreznih prihoda ubuduce bit će u potpornoj funkciji poreznog sustava gospodarskom rastu. Drugim riječima, sustav poreznih poticaja i pogodnosti trebat će dodatno razviti i ojačati. Promijenjena porezna struktura i razine prihoda tijekom pandemijske krize svakako će i nakon oporavka trebati prilagodbu, u skladu s drugim javnim politikama. To upućuje na promišljanja o novim poreznim oblicima i mjerama odnosno na preispitivanje tradicionalnih elemenata poreznog sustava. Istodobno, sprečavanje regresivnosti i nejednakosti u mjerama potpore tijekom pandemijske krize ukazuju na potvrđena razmišljanja o tome kako zadržati ili podržati progresivnost cjelokupnog poreznog sustava. U promišljanjima o novim poreznim oblicima u postkriznim potrebama oporavka, globalni i europski odgovori trebaju biti usklađeni. EU i OECD razmatraju i pitanje revizije važećih poreznih oblika, a na razini EU-a i pitanje vlastitih prihoda u proračunu Unije: porezi na ugljik, oporezivanje digitalnih

28 Heald, David, „The accounting, budgeting and fiscal impact of COVID-19 on the United Kingdom“, Journal of Public Budgeting, Accounting \& Financial Management, vol. 32, br. 5, dostupno na: https://www.emerald.com/insight/publication/issn/1096-3367 (25. XI. 2020.). 
transakcija, aktualizacija CCCTB-koncepta, poreza na financijske transakcije itd. Sve to ukazuje na složenost i sveobuhvatnost promišljanja o poreznom postkriznom okruženju. Posebno se nameću kao aktualni porezni izazovi koji nastaju u svezi s oporezivanjem digitalne ekonomije i osiguranja da MNE plaćaju makar minimalnu razinu poreza, a povećana upotreba digitalnih usluga i potreba za skupljanjem većih prihoda mogli bi ubrzati postizanje međunarodnog sporazuma. ${ }^{29}$ Porezna suradnja bit će posebno značajna kako bi se izbjegli porezni sporovi koji mogu voditi u trgovinske ratove koji bi nesumnjivo naštetili oporavku. Povećanje porezne sigurnosti, poboljšanjem mehanizama rješavanja i sprečavanja sporova, dio su potpora za oporavak i izgradnju poreznih sustava u postkriznom vremenu.

\section{ZAKLJUČNE NAPOMENE}

U rješavanju pandemijske krize velika su očekivanja od fiskalne i porezne politike u iznalaženju pomoći vladama. Kriza COVID-19 primarno je zdravstvena kriza koja ima ogroman utjecaj na gospodarstva širom svijeta pa je riječ i o posljedičnoj ekonomskoj krizi. Mjere koje vlasti poduzimaju kako bi suzbile i ublažile širenje virusa i ograničile negativne učinke na svoje građane i njihova gospodarstva primarno su epidemiološke i zdravstvene naravi, vrlo su intenzivne, a čine se, na globalnoj razini, prilično ujednačenima. Odgovori mnogih vladinih ekonomskih politika bili su brzi i opsežni. Dosadašnji fiskalni paketi usmjereni su na ublažavanje neposrednog utjecaja naglog pada ekonomske aktivnosti na tvrtke i kućanstva i na očuvanje proizvodnih kapaciteta zemalja. Iako postoje velike razlike u veličini fiskalnih paketa, većina je značajna, a neke su zemlje poduzele akcije bez presedana. Dodjela potpora koja je individualno prilagođena tamo gdje je prijeko potrebna, uključujući posebno samozaposlenje, mala i srednja poduzeća, predstavlja značajne administrativne izazove za javnu poreznu upravu. Održavanje poslovnog novčanog tijeka glavni je cilj uvedenih mjera fiskalne politike, podržanih monetarnom i financijskom politikom. Mjere su uključivale produljenje rokova za prijavu poreza, odgodu plaćanja poreza, pružanje bržih povrata poreza, izdašnije naknade za nadoknadu gubitaka i neka porezna izuzeća, uključujući poreze na doprinose za socijalno osiguranje, porez na plaću ili porez na imovinu. Zemlje su također primijenile široke mjere kako bi pomogle poduzećima da zadrže svoje radnike kroz kratkoročne programe rada ili subvencije plaća. Postoje dokazi iz politika provedenih nakon svjetske financijske krize da je zadržavanje ljudi na radu kroz takve sheme učinkovit način pružanja potpore dohotku i ograničavanju gubitka posla, istodobno izbjegavajući skupe procese pretraživanja i usklađivanja kako napreduje. Potpora dohotku domaćinstvima proširena je u mnogim zemljama, općenito ciljanim novčanim naknadama, umjesto smanjenjem poreza, s obzirom na potrebu za brzim pružanjem potpore. Postoje i slučajevi u kojima je olakšan pristup naknadama zbog bolovanja i prošireno ispunjavanje uvjeta, a nekoliko je zemalja

29 https://www.consilium.europa.eu/en/press/press-releases/2020/12/14/next-multiannual-financialframework-and-recovery-package-council-moves-to-finalise-adoption/ (20. XI. 2020.). 
proširilo pokrivenost naknadama za nezaposlenost posebno samozaposlenim radnicima. Istodobno, raznim mjerama iz područja fiskalne politike države pomažu poduzećima da opstanu, podupiru osobnu potrošnju i kućanstva te pomažu u očuvanju zaposlenosti. Ipak, naveden mjere poduzimaju se od početka ad-hoc i s ciljem kratkoročnosti, a izvjesno je da je potrebno daljnje djelovanje, sa širim i snažnijim te dugoročnijim mjerama. Neposredne mjere iz područja fiskalne politike, poduzete u kratkom vremenu od izbijanja zdravstvene i ekonomske krize, podržale su veći dio tijekova poslovanja, dohotke kućanstava i zaposlenost.

Mjere ekonomske politike usmjerene su na ublažavanje posljedica zaustavljanja i usporavanja ekonomske aktivnosti uvedenih kako bi se kontroliralo širenje zaraze. One mogu privremeno olakšati situaciju, no ne mogu promijeniti smjer očekivanja sve dok tržišta ne povjeruju u smanjivanje restrikcija gospodarske aktivnosti unutar pojedinih zemalja i između zemalja.

Hrvatsko je gospodarstvo čvrsto povezano s europskim, a indikatori gospodarske aktivnosti za razdoblje cijele 2020. godine upućuju na snažno smanjenje gospodarske aktivnosti u EU-u, usporedivu s padom zabilježenim nakon izbijanja globalne financijske krize. Međutim, budući da je pad rezultat vanjskog šoka, odnosno brzog širenja pandemije i oštrih mjera poduzetih za njezino suzbijanje, a ne unutarnjih poremećaja u gospodarskom ili financijskom sustavu, daljnja evolucija gospodarske aktivnosti ovisit će upravo o uspješnosti borbe s virusom i restrikcijama gospodarske aktivnosti. Instrumenti javnih financija zbog posebnih okolnosti nastanka i upravljanja krizom traže prilagodbu ili izgradnju novih. Javne politike, posebno fiskalna, imaju zadatak pratiti i podupirati nove zdravstvene i ekonomske izazove koji su u nastanku. Epidemiološke mjere poput ograničenja kretanja i obavljanja nekih djelatnosti trebat će uklanjati postupno, a oporavak će biti vrlo nejednak, na nacionalnoj ali i na globalnoj razini. Slabiji oporavak traži jaču fiskalnu intervenciju i djelovanje, a europska i međunarodna multilateralna suradnja neophodne su za oporavak i jačanje otpornosti globalnog gospodarstva na eventualne i buduće krize i šokove. U tom smislu potrebna će biti posebna fiskalna podrška, uključujući europsku, ali i međunarodnu koordinaciju, posebnu financijsku potporu te prilagodbu fiskalnih i poreznih pravila koja idu u korist svim zemljama. Svojevrsno propitivanje, kao i obnova javnih financija, bit će potrebni, što znači korekciju nekih postojećih instrumenata, ali i promišljanje o novim instrumentima javnih financija, posebno kroz prizmu kontinuiranih napora u rješavanju međunarodnih poreznih izazova koje predstavljaju digitalizacija gospodarstva i borba protiv neplaćanja poreza. Porezna i fiskalna politika, dajući odgovor na krizu izazvanu koronavirusom, ukazuju da je potrebno raditi na jačanju povjerenja i otpornosti cijelog fiskalnog sustava za sve buduće izazove. 


\section{CONSEQUENCES AND EFFECTS OF THE COVID-19 PANDEMIC ON FISCAL SYSTEMS AND TAXATION}

Public policy's answer to the COVID-19 pandemic in the majority of countries worldwide has greatly and directly influenced fiscal systems. The measures undertaken in all public policy to combat or reduce the pandemic are reflected in fiscal politics in all its segments, which is particularly evident in the expense and profit sections because it concerns the effect on budgets and their expense and profit aspects. A clear, fiscal response to the health and consequential, wider economic crisis demonstrates the success or otherwise of financial management of the public sector. Crisis indicators present the dramatic effects on public financing and the fiscal system as a whole. The fiscal system with its measures at the same time is both an instrument in the battle against the Covid pandemic and is affected by the pandemic: public profits in first three months were reduced by $15-30 \%$, and at the same time, expenses were increased by approximately $30-40 \%$ in comparison with the same period last year. Such a negative effect has been increased by the growing deficit and growing public debt. The measures undertaken within the framework of all public policies are all short term and subject to constant adjustments which is necessary given the fast changing social, economic, welfare, and fiscal environment and circumstances. It is possible to monitor the coordination in response to the crisis at both an international and European level as well as the national reaction and measures to the crisis. The OECD and European Union are preparing long-term measures and instruments, and at Union level has, along with other instruments, offered the temporary instrument of SURE. The time dimension of the undertaken measures is significant given the speed at which all the aforestated circumstances are changing. The high rate of indebtedness of the private and public sector which is increasing during the Covid pandemic will have long term consequences on the fiscal system overall. The types and means of decision making about all the measures to combat the Covid pandemic and their fiscal effects, even after the end of the pandemic crisis, could slow down the soon to be announced fiscal decentralization. Public finances will experience adjustment, through the application of both classic and adapted instruments and the creation of new instruments of fiscal policy to combat both existing and possible future crises.

Key words: fiscal system, public policy measures, Covid pandemic and crisis, SURE, public finances 